\title{
P59. Depleting the suppressors for the benefit of immunotherapy against cervical cancer
}

\author{
O Draghiciu ${ }^{1 *}$, BN Hoogeboom¹, T Meijerhof ${ }^{1}$, HW Nijman², CAHH Daemen ${ }^{1}$ \\ From 1st Immunotherapy of Cancer Conference (ITOC1) \\ Munich, Germany. 12-14 March 2014
}

\section{Background}

Cancer vaccines aim at inducing tumour-specific immune responses. However, in clinical studies so far these approaches have limited antitumour effect. Evidence is accumulating that MDSC (myeloid-derived suppressor cells) can suppress the antitumour immune response. Reversal of MDSC-mediated immune suppression by treatment with the tyrosine kinase inhibitor sunitinb can therefore possibly increase the efficacy of cancer vaccines.

\section{Material and methods}

We developed a method to assess MDSC depletion in a preclinical model of HPV-induced neoplasia. TC-1 (cells expressing HPV16-E7) tumour-bearing mice were injected with different dosages of sunitinib daily, for 9 days, with and without immunisation with SFVeE6,7 (Semliki Forest virus encoding human papilloma virus E6,7 tumor antigens). Intra-tumoral, intra-splenic and circulating MDSC and CD8 T cell levels were assessed after treatment.

\section{Results}

Upon sunitinib treatment, the absolute numbers of intratumoral, intra-splenic and circulating MDSC decreased in a dose-dependent manner. Combined sunitinib and immunisation therapy led to a marked decrease of intratumoral, intra-splenic and circulating MDSC levels as compared to non-treated control or immunisation alone. The bi-therapy regimen markedly enhanced intra-tumoral, intra-splenic and circulating levels of CD8 T cells. The highest number of circulating CD8 $\mathrm{T}$ cells undergoing degranulation $(\mathrm{CD} 107 \mathrm{ab}+)$ was observed after combined treatment. Most importantly, this combined sunitinib and immunisation treatment regimen abrogated tumour growth.

'University Medical Center Groningen, Medical Microbiology, Groningen, the Netherlands

Full list of author information is available at the end of the article

\section{Conclusions}

In summary, we demonstrated that sunitinib alone or in combination with immunisation can decrease intratumoral, intra-splenic and circulating MDSC levels. Also, combination of sunitinib treatment with immunisation enhanced levels and degranulating activity of CD8 T cells, thus resulting in reversal of tumour growth. This study indicates that SFV-based immunotherapy combined with sunitinib treatment could improve treatment outcome.

\section{Authors' details}

'University Medical Center Groningen, Medical Microbiology, Groningen, the Netherlands. ${ }^{2}$ University Medical Center Groningen, Gynaecology, Groningen, the Netherlands.

Published: 12 March 2014

doi:10.1186/2051-1426-2-S2-P33

Cite this article as: Draghiciu et al:: P59. Depleting the suppressors for the benefit of immunotherapy against cervical cancer. Journal for ImmunoTherapy of Cancer 2014 2(Suppl 2):P33.

Submit your next manuscript to BioMed Central and take full advantage of:

- Convenient online submission

- Thorough peer review

- No space constraints or color figure charges

- Immediate publication on acceptance

- Inclusion in PubMed, CAS, Scopus and Google Scholar

- Research which is freely available for redistribution 